\title{
ECONOMIC DEVELOPMENT OF THE REPUBLIC OF SERBIA DETERMINED BY THE SECTORAL STRUCTURE OF THE ECONOMY
}

\author{
Vladimir Micic* \\ Faculty of Economics, University of Kragujevac, Kragujevac, The Republic of Serbia
}

Experience and good practice show that, in order to achieve economic growth and development, changes in the economic structure need to be made. They have an influence on the relative share, place and role of certain activities in the economy and they are the driver of sustainable economic development. Efficient structural changes are related to the capability of an economy to create more propulsive economic activities. The subject matter of the research in this paper is the determination of the degree of the determination of the economic development of the Republic of Serbia by the sectoral structure of the economy. The research goal is to indicate the adequacy of the size of and contribution of the sectors to the creation of gross value added and the total employment, i.e. the influence of the size, intensity and directions of changes between the sectors on the economic development. The research results are indicative of the fact that the achieved level of the development and low growth rate of the economy of the Republic of Serbia are the consequence of insufficiently comprehensive and intensive changes, changes that are late and are not stable. The future development of the economy will directly depend on the speed of changes and the creation of a modern sectional economic structure, especially the development of a propulsive manufacturing structure or " 4.0 industries".

Keywords: economic development, structural changes, economic growth rate, employment, value added

JEL Classification: L16, O11,047, E24, H24

\section{INTRODUCTION}

Economic development is a multidimensional and complex process; apart from economic growth, it also encompasses changes in the structure of an economy, as well as changes in resources,

* Correspondence to: V. Micic, Faculty of Economics, University of Kragujevac, D. Pucara 3, 34000 Kragujevac, The Republic of Serbia; e-mail: micicv@kg.ac.rs institutions, technology and processes and numerous other changes in a social system. When developing countries are concerned, such as the Republic of Serbia (RS), structural changes are necessary so as to ensure in order to faster growing gross domestic product (GDP) per capita. Practice shows that, in order to achieve sustainable economic growth and development, efficient changes in the economic structure need to be made. They have an 
influence on the creation of propulsive activities, whereas the growth of the GDP per capita has an influence on the achievement of the reallocation of the labor force and newly-created value from laborand resource-intensive activities, as well as the activities that are knowledge- and technology-more intensive.

The economic structure is a factor influencing the economic growth and development of a national economy, thus including those of RS. Therefore, the subject matter of the research in this paper is the determination of the degree of the determination of the economic development of RS by the sectoral structure of the economy.

The research goal is to indicate the adequacy of the size of and contribution of the sectors to the creation of gross value added and the total employment, i.e. the influence of the size, intensity and directions of changes between the sectors on the economic development.

In accordance with the established subject matter and goal, the paper will test the research hypothesis that the level and speed of the development of the economy and economic sectors of RS are connected with the size, intensity and direction of changes in its structure.

In the research, the secondary sources of data from the statistical base of the Statistical Office of the Republic of Serbia for the growth rates of the economy and the sectors, newly-created value and the total employment will be used. In the paper, the standard deviation will be used to measure the sizes of the structural changes as per sectors. The intensity of the structural changes of the sectors will be examined will be examined by the elasticity of the growth rates of the sectors. By applying the correlation of the growth rate ranks of the sectors, the direction of the structural changes of the sectors of the economy of RS will be analyzed. The data will be processed and analyzed by using the SPSS statistical package.
An economy consists of the activities producing tangible goods i.e. tradable goods and the activities producing intangible goods i.e. goods impossible to trade. The sectors of an economy are defined according to the manufacturing principle or the statistical classifications of activities of the United Nations (UN) and in the European Union (EU). According to these classifications, all activities are categorized at the highest hierarchical level into sections. In this paper, the data are aggregated at the level of 21 activities, according to which the economy is divided into 21 sections in total.

The structure of the paper is organized into seven parts. In the second and the third parts, the theoretical frameworks of the analysis of the economic structure, the structural changes and their types are presented. The fourth part is dedicated to the analysis of the basic indicators and the measuring of the structural changes. The fifth part is the presentation of the sectional structure of the national economy and the statistical classification of the economic activities. The sixth part contains the results of the research or the role of the economic sectors in the economic growth and development of RS. In the seventh part, the conclusions and certain recommendations are presented.

\section{LITERATURE REVIEW}

The economic structure is an important factor influencing economic development. Most frequently, the economic structure implies a whole consisting of the parts that are related to each other in a certain way and interdependently. Such a whole is changeable, and changes are influenced by different factors. The structure of foreign trade and the balance of payments depends on it, and it is also connected with technical progress, innovations, labor productivity, employment, inflation, the economic system, the economic policy, and even with specific factors, such as culture (Marjanović, 2010, 370). 
Should an economy be observed as a whole consisting of parts, then a change in any one of such parts or in the manner in which such parts are connected with one another means a change in the economic structure. It is in an uninterrupted process of changing, but those changes are not fast and frequent (Bortis, 2000, 186). The cumulative and long-term processes of technological changes and learning are the reason for that (Upadhyaya \& Yeganeh, 2015, 10-11). Structural changes are narrowly connected with the reallocation and redistribution of labor force, as well as of the other factors of economic growth, between the economic activities.

The analysis of the economic structure and the explanations of structural changes are different in growth theories and development models. It is J. A. Schumpeter himself who, considering the role of different development factors, first of all the role of entrepreneurs and technological changes in economic development, highlighted the fact that innovations and their application through imitations and further improvements were the basic driver leading to structural changes in an economy (Croitoru, 2012, 137-148).

While the structure and structural changes are the focal point of attention of classical economics, neoclassical economics considers structural changes to be a result of the market development and that the same are not a condition necessary for economic development. The theories of structural changes pay most attention to the economic structure, structural changes and development patterns (Lewis, 1954, 139-191; Chenery, 1975, 310316). They are directed towards the mechanism by means of which undeveloped economies transform their own economic structures from traditional agriculture towards industry and diverse services. By applying neoclassical price theory, resource allocation and models, they tend to explain how the process of the transformation of the economic, industrial and institutional structures is initiated and also to econometrically quantify the significance of structural changes as a factor of economic growth as precisely as possible. According to them, both the growth pattern and the development of an economy depend on the internal factors (accumulation, investment, resource use, the population size, the demand structure, urbanization, institutional limitations, changes in social-economic factors) and the external factors (of which the most significant are the transfer of technology from abroad and international trade).

The economic crisis of the late 1960s and the early 1970s, which according to a general assessment had a structural character, led to researching the causes and the factors, and especially to the size, degree, speed and directions of the structural changes of the economy, which had the statistical series of the growth rates of the sectors as their basis. According to these research studies, structural changes imply different arrangements of manufacturing activities in the economy and the different distribution of the manufacturing factors among different sectors of the economy, different activities, regions and types of products (Machlup, 1991, 76).

When endogenous theories are concerned, technology takes the central place in the explanation of structural changes and economic development (Baldwin, Braconier \& Forslid, 2005, 495). They also examine the role of research and development, the infrastructure, the state, as well as institutional factors and organizations. They also include the role of the intangible factors in the explanation of structural changes, such as the organizational structure, managerial capabilities and culture.

In the economic literature, structural changes are considered to be influencing the relative share, significance and location of certain wholes and parts in the economy and to also be an important driver of economic development (Syrquin, 2008, 48). Although they are mainly universal, the relations, speed and directions of structural changes depend on the specificities of an economy (Cimoli \& Katz, 2003, 387-411). Efficient structural changes 
are important for the growth of productivity, as well as for an efficient allocation of resources and taking advantage of technology and innovations (Fagerberg, 2000, 393-411). When developing countries are concerned, structural changes are necessary so as to ensure faster progress into a higher development level (Lin, 2012, 5), i.e. in order to reach the countries with a higher level of the GDP per capita.

Today, apart from innovations and new technologies as the main drivers of structural changes, knowledge, investments, externalities, skills, use of resources, offer and demand, international trade, relationships and agglomerations, institutional frameworks, globalization are also highlighted (UNIDO, 2013, 16).

What is quite important is that structural changes have an influence on the creation of the economic policy as a conscious influence of a state on the achievement of certain developmental goals. An economic policy can have either a positive or a negative influence on changes in the economic structure, by driving it more closely to or moving it farther away from its optimum (Marjanović, $2015,67)$. Because of that, the capability of the state to shape and influence the structure of the economy and the structure of particular sectors by implementing an adequate economic policy, i.e. to implement structural changes efficiently, continuously and actively in compliance with available factors which development rests on, is also important (Mićić, 2016, 153-161).

In the theory and practice of economic development, there are three basic types of structural changes that are specially singled out and recognizable: industrialization, deindustrialization and reindustrialization.

During the process of industry development, changing the manufacturing manner is to a substantial extent conditioned by major changes and technical and technological innovations, or more exactly by industrial revolutions or inventions and the improvement of new products, machines and technologies. The First Industrial Revolution was initiated by the steam engine, the Second by electric energy and conveyor belts, and the Third by electronics, computers and robotics. The newlyemerging, Fourth Industrial Revolution is of a global character and rests on the development of the "4.0 industries" i.e. integrated industry. Due to an accelerated cycle of technical innovations, it influences all the participants in the chain of industrial manufacturing and changes the structure of both industry and economy. It is based on a series of new trends and technologies, first of all on artificial intelligence, knowledge and new generations of digital technologies and the digital infrastructure.

Industrialization encompasses a complex of structural changes made due to technical innovations, through which the share of industry in the creation of the GDP and employment is increased, simultaneously continually decreasing the share of agriculture and the growth of the share of the service sector. Practice has shown that in undeveloped countries, in which the agrarian structure is predominant, industrialization has led to economic development and change in the economic structure. In all phases of economic development, industry has a dominant influence on the economic structure, for which reason the other two types of structural changes, namely reindustrialization and deindustrialization, are also brought into connection with technical innovations and industrial development. These two processes and types of structural changes are parallel and in a cause-and-effect connection.

Deindustrialization is a process of structural changes characterized by a reduction in the share of industry and growth of the share of the service sector in the GDP and employment. It is a long-term process, which is to a certain extent different from one country to another (Timmer \& Akkus, 2008, 7). The correlation of trends between the level of the GDP per capita, sectoral contribution to the creation 
of the GDP, value added, employment distribution and labor productivity is the common feature of this process. Deindustrialization leads to the tertiarization of the economic structure thanks to the powerful development of the service sector.

A difference must be made between deindustrialization as a positive and as a negative process (Rowthorn \& Ramaswamy, 1997, 1-2). In a positive sense, it denotes the maturity of the industry whose manufacturing is based on science, knowledge and technical innovations. The classes of high technological intensity and a high intensity of using working skills and knowledge have a dominant share, by which the identity of the classical industrial structure is lost. In a negative sense, it results in bad economic performances of an economy. Most frequently, it is caused by a wrong strategy of the development of an industry in the crucial phases of its development.

Reindustrialization is related to change in the developmental paradigm, according to which successful development is no longer in possessing natural resources and capital, but it has increasingly been dependent on technology, innovations, research, knowledge and the quality of the labor force. Today, these factors are the basis of reindustrialization, the creation of modern, technologically new, sophisticated, knowledge-intensive, ecologically responsible and energy-efficient industries that employ highlyqualified labor force. New technologies, based on nanotechnologies, microelectronics, robotics, the 3-D print process, biotechnology and genetic engineering, new materials, ecological cars and vehicles, ecological transport, smart networks for energy transmission and so forth have been developed and used with an ever increasing speed.

Innovations, research and education are the foundations of reindustrialization and the development of a strong, dynamic and sustainable industrial base (European Commission, 2012, 3), which contributes to structural changes and sustainable economic growth, the creation of new jobs, ecological efficiency, the development of new products with high value added and the creation of a knowledge-based economy. Apart from its direct contribution to the development of industrial productivity, reindustrialization also has an influence on the growth of the productivity of the other sectors, especially of the service sector, namely by the scope of investment in new technologies. More precisely, it is in the center of a new model of economic growth and the development of a larger number of highly-developed and fast-growing economies.

\section{MEASURING STRUCTURAL CHANGES AND THE STATISTICAL CLASSIFICATION OF ECONOMIC ACTIVITIES}

There are numerous indicators of structural changes. The most frequently used, however, are the indicators that measure changes in the sectoral structure of an economy with respect to manufacturing, employment, value added, export, knowledge, innovations, technology and investments. While carrying out a quantitative analysis of structural changes in an economy as per sector, the most frequently used data are those related to the share of certain sectors in the GDP, gross value added (GVA) and employment.

The size of the structural changes as per sectors can be measured by the standard deviation of the growth rates of those sectors. The standard deviation of the growth rates as per sectors is directly proportional to the dispersion of the growth rates of the sectors and the structural changes between those sectors. A greater dispersion shows that structural changes are bigger, whereas a smaller dispersion means that structural changes are smaller (Savić, Bošković \& Mićić, 2015, 30).

For the purpose of the analysis of the intensity of structural changes, two approaches can be used. 
Regarding the first approach, the intensity of the structural changes at the sectoral level is calculated on the basis of the relative growth rates of each sector. Those rates are obtained as $\mathrm{Q}_{\mathrm{i} 1} / \mathrm{Q}_{\mathrm{i} 0}: \mathrm{P}_{1} / \mathrm{P}_{0}$ or as $\left(\left(\mathrm{Q}_{\mathrm{i} 1} / \mathrm{P}_{1}: \mathrm{Q}_{\mathrm{i} 0} / \mathrm{P}_{0}\right)-1\right) \times 100$. In the first case, change in the size of an individual sector $Q_{i}$ with the aggregate size of $\mathrm{P}$ is determined, whereas the subject matter of the determination in the second case is the share of an individual segment of the structure in the total size. The indicator of structural changes is obtained as the arithmetical average of the sum total, which is weighted by the share of relative growth rates in the total expression. The second approach uses the elasticity of growth rates for the analysis of the intensity of structural changes at the level of a sector. They are calculated by dividing the growth rate of the observed sector by the growth rate of the economy (Roman, 1969, 265-268). If a coefficient greater than one is obtained, it means that the sector is increasing its share, thereby increasing their role and significance in an economy as well.

Together with these indicators, the correlation of the activities' growth rate ranks is frequently used. It is used to analyze the directions of the structural changes of those sectors, whereas the direction of the structural changes is shown by the Spearman Rank Correlation Coefficient for the growth rates of the sectors for consecutive pairs of years (Savić et al, 2015, 31). Rank correlation is high if changes are constantly made in favor of the same sectors, and it is low if the directions of changes are frequently changed between the sectors of the economy.

Also, the economic structure in one year can be expressed as the n-dimensional vector, too. The coordinates of that vector represent the share of certain sectors in the aggregate size, such as the GDP. Structural changes are mirrored in the change in the coordinates of those vectors. Dynamically observed, the differences between the structures of the vectors in certain years can be expressed by a cosine between those vectors (Moore, 1978, 107).

Different economic activities of manufacturing and services are classified into economic sectors. The sectors can be divided and grouped according to a larger number of the criteria, and the phases in the manufacturing chain, according to which they are grouped into the primary, the secondary and the tertiary sectors, are most frequently used. The tertiary sector has become the most heterogenic over time because it has spread and differentiated itself the most. Therefore there is an aspiration that the tertiary sector must further be differentiated into the quaternary sector in the economically and industrially most developed countries.

Since an economy can consist of quite different, dynamic and heterogenic activities, due to the temporal and spatial comparability of data, the statistical classification of the economy and economic activities according to the manufacturing principle is most frequently used in economic analyses today. For the needs of this paper, the statistical classification of the economic activities of the EU that has been derived from the industrial classification of the economic activities of the UN will be used (European Commission, 2008, 11-17).

The official statistical division of all economic activities is done according to the International Statistical Classification by the UN (United Nation, 2008, 1-21). Its title is: United Nation's International Standard Industrial Classification of all Economic Activities - ISIC). For the most part, ISIC is followed by the EU Standard Classification (NACE1). According to the NACE and ISIC classifications, all the activities are classified into sectors at the highest hierarchical level.

NACE and ISIC provide a framework for the collection and demonstration of a large scope of statistical data according to economic activities both in the field of economic statistics (manufacturing, employment, national accounts) and in the other statistical fields. NACE is derived and represents a part of the ISIC Classification. The categories at all the NACE levels are defined so as to be identical to the ISIC Categories. ISIC and NACE have the same 
number of the categories at the highest level, but NACE provides more details at the lower levels. The ISIC first and second levels, Revision 4, i.e. the sections and divisions of the economy, are identical to the NACE sections and divisions, Revision 2. The third and the fourth levels, namely the groups and the classes, are divided in a more detailed manner in NACE, Revision 2, according to the European needs. The goal of more detailed divisions in NACE, Revision 2, is to obtain a classification more adapted to the structures of the European economies.

Since 2011, RS has been applying the Classification of Activities from 2010, within the process of compliance with the standards of the EU and the European Statistical System. The new Classification of Activities is the EU standard classification of activities from 2008, taken over without any changes (SOR, 2010, 4).

\section{ROLE OF THE SECTIONS OF THE ECONOMY IN THE ECONOMIC GROWTH AND DEVELOPMENT OF THE REPUBLIC OF SERBIA}

The structure of the economy of RS as per sections, as well as change in that structure, is accounted for in Table 1. Observed as per sections, the sections of Manufacturing (C) with 15.6\%, Wholesale and retail trade; repair of motor vehicles and motorcycles (G) with 10.2\%, Real estate activities (L) $8.9 \%$ and Agriculture, forestry and fishing (A) with 6.8\% had the most significant share in the formation of the GDP, i.e. made the greatest contribution to the creation of GVA in 2014.

Apart from a high share of the Manufacturing and Agriculture, forestry and fishing sections in the creation of the GDP, the economic structure of RS has been changed since 2001 in favor of the service sector, which has the biggest sectional share.
Table 1 The structure of the GDP of the Republic of Serbia

\begin{tabular}{|c|c|c|c|c|}
\hline Sections & 2001. & 2009 & 2014 & ${ }^{*}+1-$ \\
\hline$A$ & 18.2 & 8.0 & 6.8 & -11.4 \\
\hline B & 1.2 & 1.3 & 1.0 & -0.2 \\
\hline$C$ & 21.7 & 13.6 & 15.6 & -6.1 \\
\hline D & 0.6 & 3.2 & 3.7 & 3.1 \\
\hline E & 0.8 & 1.1 & 1.1 & 0.3 \\
\hline $\mathrm{F}$ & 3.5 & 4.1 & 4.5 & 1.0 \\
\hline G & 7.6 & 9.5 & 10.2 & 2.6 \\
\hline $\mathrm{H}$ & 3.7 & 4.7 & 4.4 & 0.7 \\
\hline I & 0.9 & 1.0 & 1.1 & 0.2 \\
\hline$J$ & 3.3 & 4.2 & 4.4 & 1.1 \\
\hline K & 1.8 & 3.1 & 3.0 & 1.2 \\
\hline L & 13.2 & 10.9 & 8.9 & -4.3 \\
\hline M & 1.8 & 3.6 & 3.3 & 1.5 \\
\hline $\mathrm{N}$ & 0.9 & 1.4 & 1.4 & 0.5 \\
\hline 0 & 6.4 & 3.3 & 3.5 & -2.9 \\
\hline $\mathrm{P}$ & 2.3 & 4.4 & 2.9 & 0.6 \\
\hline Q & 3.7 & 5.5 & 4.5 & 0.8 \\
\hline $\mathrm{R}$ & 0.7 & 1.3 & 1.0 & 0.3 \\
\hline$S$ & 0.6 & 1.4 & 1.4 & 0.8 \\
\hline $\mathrm{T}$ & 0.1 & 0.1 & 0.1 & 0.0 \\
\hline U & - & - & - & - \\
\hline GVA & 93.1 & 85.8 & 82.8 & -10.3 \\
\hline $\begin{array}{l}\text { Taxes on } \\
\text { products }\end{array}$ & 6.2 & 13.5 & 17.8 & 11.6 \\
\hline $\begin{array}{c}\text { Subsidies on } \\
\text { products }\end{array}$ & 0.7 & 0.7 & 0.6 & -0.1 \\
\hline GDP & 100.0 & 100.0 & 100.0 & - \\
\hline
\end{tabular}

Source: Author, based on: RZS, 2017

The dynamic growth of the service sector in the GDP until 2008 was achieved thanks to an increase in the share of, first of all, the sections of Wholesale and retail trade; repair of motor vehicles and motorcycles, Information and communication, Financial and insurance activities and Professional, scientific and technical activities. These sections 
based their propulsion and higher growth rates on investments, especially in telecommunications, the liberalization of exports, the growth of personal consumption, privatization and the restructuring of the banking and financial sectors. The growth of the share of the service sector, together with a reduction in the share of the real sector, especially the sections of Manufacturing and Agriculture in manufacturing and employment, are the usual marks of the transition process and the tertiarization of the economy.

The number of workers slightly increased in the economy of RS in 2015 (Table 2). Simultaneously, the number of the employed in the sections of Manufacturing (C) and Accommodation and food service activities (I) was reduced by 16,000 per each, whereas in the section of Wholesale and retail trade; repair of motor vehicles and motorcycles $(G)$, their number was reduced by over 20,000. Apart from that, the sectional changes of the employed are characterized by an ever-increasing number and percentage of the employed in the service sector.

Yet, since 2010, the service sector has not been capable of creating a sufficient number of new jobs, especially due to the consequences of the Global Economic Crisis so as to compensate for the fall in industry. For that reason, a part of the labor force is being reallocated from industry to the primary sector, especially to agriculture. Also, it is a fact that the reallocation of the labor force within the sectors is still dominant over reallocation between the sectors. A high unemployment rate is the major issue, as a result of inefficient structural changes, which bears special importance from the social and developmental point of view (Jakopin, 2012, 86).

According to the manufacturing principle, in 2015, there were about 452,000 employees in the sections of Mining and quarrying (B), Manufacturing (C) and Electricity, gas, steam and air conditioning supply (D), whereas there were about 538,000 employees in the sections of Agriculture, forestry and fishing (A). At the same time, the relative share of the employed in the three sections of industry (B, C, and D) is about $18.4 \%$ in the total number of employees, whereas the relative share of the employed in the section of Agriculture, forestry and fishing accounts for $21.9 \%$. This is the best indicator of what the level of economic development and the reallocation of the labor force are, of how inefficient the structural changes in the economy are, of the condition in which the industry is, and most importantly, what and how significant its role in the economic development of RS is.

Table 2 The total number and structure of the employed, 2010-2015

\begin{tabular}{c|rrrrr}
\hline Sections & \multicolumn{1}{|c}{2010.} & \multicolumn{1}{c}{$\%$} & \multicolumn{1}{c}{2015.} & \multicolumn{1}{c}{$\%$} & \multicolumn{1}{c}{$+l^{*}$} \\
\hline A-U & $2,396,244$ & 100.00 & $2,459,048$ & 100.00 & 62,804 \\
\hline A & 532,969 & 22.24 & 538,040 & 21.88 & 5,071 \\
B & 23,316 & 0.97 & 29,198 & 1.19 & 5,882 \\
C & 401,711 & 16.76 & 385,369 & 15.67 & $-16,342$ \\
D & 36,293 & 1.51 & 37,386 & 1.52 & 1,093 \\
E & 41,097 & 1.72 & 35,548 & 1.45 & $-5,549$ \\
F & 120,689 & 5.04 & 120,476 & 4.90 & -213 \\
G & 326,283 & 13.62 & 305,493 & 12.42 & $-20,790$ \\
H & 125,563 & 5.24 & 121,550 & 4.94 & $-4,013$ \\
I & 71,610 & 2.99 & 55,442 & 2.25 & $-16,168$ \\
J & 47,682 & 1.99 & 49,253 & 2.00 & 1,571 \\
K & 44,852 & 1.87 & 40,839 & 1.66 & $-4,013$ \\
L & 3,268 & 0.14 & 2,467 & 0.10 & -801 \\
M & 57,053 & 2.38 & 61,701 & 2.51 & 4,648 \\
N & 37,694 & 1.57 & 56,725 & 2.31 & 19,031 \\
O & 120,459 & 5.03 & 138,827 & 5.65 & 18,368 \\
P & 159,381 & 6.65 & 164,215 & 6.68 & 4,834 \\
Q & 157,137 & 6.56 & 141,713 & 5.76 & $-15,424$ \\
R & 36,964 & 1.54 & 45,794 & 1.86 & 8,830 \\
S & 47,627 & 1.99 & 49,499 & 2.01 & 1,872 \\
T & 3,770 & 0.16 & 78,810 & 3.20 & 75,040 \\
U & 825 & 0.03 & 705 & 0.03 & -120 \\
\hline
\end{tabular}

* +/- 2015 as compared to 2010

Source: Author, based on: RZS, 2017 
The data show that, since 2008, the share of the tertiary sector has been the only one to have recorded the growth of employment, namely from $48.7 \%$ to $53.4 \%$. The share of the secondary sector has been reduced from $25 \%$ to $23.5 \%$, whereas the primary sector has reduced its share from $26.3 \%$ to $23.1 \%$.

It can be assessed that, in comparison with the EU average, where the share of the employed in the primary sector accounts for around 5\%, in the secondary sector around $17 \%$ and the tertiary sector around $78 \%$, the sectoral structure of the employed in the economy of RS significantly deviates from it.

The previous analysis at the level of the sectors of the economy of RS, quantified by the share in the GDP and employment, shows that bigger structural changes between the sections correspond with bigger fluctuations of the growth rates of those sections. This is also confirmed by the standard deviation, as well as by the dispersion of the growth rates as per sections, which are directly proportional to the fluctuation of the growth rates of the observed sections (Table 3).

What is not good for structural changes is the fact that the sections whose share is bigger and whose growth rates record bigger fluctuations do not have an increasing share in the structure and do not drive changes in the economy. Namely, the standard deviation shows that structural changes in those sectors are the declining, rather than growing function of the growth rates. The smallest structural changes have been made in the sections of Human health and social work activities (Q), Education (P) and Real estate activities (L), whereas the biggest changes have been recorded by the sections of Construction (G), Water supply; sewerage, waste management and remediation activities (E) and Agriculture, forestry and fishing (A). The other sections have been recording more moderate standard deviations of the growth rates as per years.
Table 3 The standard deviation and descriptive statistics, 2001-2014

\begin{tabular}{c|cccc}
\hline Section & Min. & Max. & Average & $\begin{array}{c}\text { Standard } \\
\text { deviation }\end{array}$ \\
\hline A-U & -3.6 & 8.8 & 2.414 & 0.8630 \\
\hline A & -17.3 & 20.9 & 2.086 & 2.9431 \\
B & -23.3 & 9.0 & -0.571 & 2.2400 \\
C & -15.8 & 6.4 & 0.329 & 1.4912 \\
D & -28.8 & 13.0 & 0.014 & 2.6227 \\
E & -12.6 & 3.7 & -1.064 & 1.1986 \\
F & -19.7 & 36.1 & 4.607 & 3.7874 \\
G & -7.5 & 19.0 & 6.929 & 2.3586 \\
H & -10.0 & 11.3 & 3.679 & 1.4974 \\
I & -10.0 & 7.9 & -1.471 & 1.1660 \\
J & -3.9 & 27.1 & 11.721 & 2.4923 \\
K & -9.5 & 17.8 & 4.121 & 2.1327 \\
L & -1.3 & 4.1 & 1.593 & 0.4035 \\
M & -7.5 & 10.2 & 2.979 & 1.1835 \\
N & -4.3 & 23.0 & 5.550 & 2.1389 \\
O & -2.9 & 4.7 & 1.229 & 0.6103 \\
P & -3.4 & 1.4 & -0.450 & 0.4058 \\
Q & -3.0 & 2.8 & 0.364 & 0.3807 \\
R & -10.2 & 10.1 & 2.179 & 1.3346 \\
S & -12.0 & 12.4 & 0.800 & 1.6699 \\
T & -6.7 & 8.5 & 2.071 & 1.1554 \\
U & n.d.a. & n.d.a. & n.d.a. & n.d.a. \\
\hline n. & & & &
\end{tabular}

n.d.a. - no data available

Source: Author, based on: RZS, 2017

The practical experiences of the economic development of other countries show that more propulsive, higher and sustainable growth rates of certain sectors of the economy have an influence on the direction of development and the creation of a modern economic structure of an economy. The trend of the maximum and minimum growth rates of the sections of the economy of RS does not confirm this. The sections that have recorded the highest growing rates have also recorded the highest fall rates, which is especially the case in 
the real sectors of the economy, which manufacture exchangeable goods (A-F). The situation is somewhat better in certain service sectors (G-R).

For a more dynamic manufacturing structure in RS, the influence of the market only was not sufficient, it was necessary for the effective implementation of economic policy, first of all the agrarian and industrial policies, especially when triggering off the key factors of structural changes. Unfortunately, this did not happen, so the growth rates could not have been higher, not even the growth rates of some traditional sections of the economy and activities, such as agriculture and food industry (Savić et al, 2015, 25-45).

The intensity of the structural changes of the sections of the economy of RS is examined by the elasticity of the growth rates of the sections. In the sections in which the calculated elasticity coefficient is greater than one, there is an increase in their share in GVA, which also increases their importance for and contribution to the economic development of RS (Figure 1).

Researching the intensity of the changes shows that they are the highest in the sections of Information and communication (J), Wholesale and retail trade; repair of motor vehicles and motorcycles (G), Administrative and support service activities $(\mathrm{N})$, Construction (F) and Financial and insurance activities (K). This fact is not confirmed only by the elasticity of the growth rates of the observed sections, but also by their average growth rate after 2001. The intensity of the structural changes of these sections was influenced by privatization and the size of investments in those sections.

The Spearman Rank Coefficient of Correlation between the growth rates for the consecutive pairs

The elasticity of growth rates

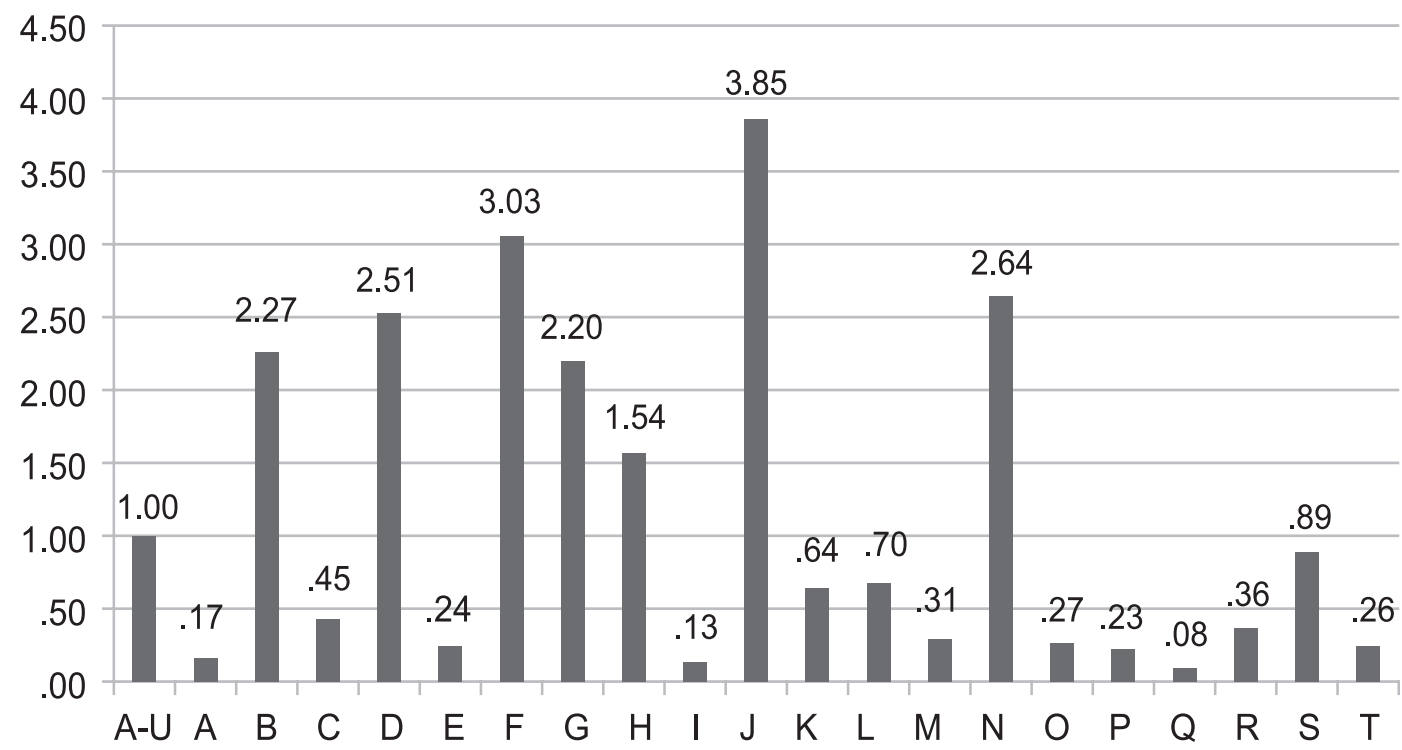

Figure 1 The intensity of the structural changes, 2001-2014. 
of years, for the 20 sections of the economy of RS, shows the direction of the structural changes between those sections (Table 4). For the $21^{\text {st }}$ section, Activities of extraterritorial organizations and bodies (U), there are no comparable data in the observed time period.

Table 4 Spearman Rank Coefficient of Correlation, 2001-2014

\begin{tabular}{c|ccc}
\hline $\begin{array}{c}\text { Consecutive } \\
\text { pairs of } \\
\text { years }\end{array}$ & $\begin{array}{c}\text { Coefficient of } \\
\text { Correlation }\end{array}$ & $\begin{array}{c}\text { Sig. } \\
\text { (2-tailed) }\end{array}$ & $\mathrm{N}$ \\
\hline $2001 / 2002$ & 0.277 & 0.238 & 20 \\
$2002 / 2003$ & 0.295 & 0.207 & 20 \\
$2003 / 2004$ & 0.011 & 0.965 & 20 \\
$2004 / 2005$ & 0.427 & 0.060 & 20 \\
$2005 / 2006$ & $0.614^{*}$ & 0.004 & 20 \\
$2006 / 2007$ & 0.441 & 0.052 & 20 \\
$2007 / 2008$ & 0.352 & 0.128 & 20 \\
$2008 / 2009$ & $0.611^{*}$ & 0.004 & 20 \\
$2009 / 2010$ & 0.395 & 0.084 & 20 \\
$2010 / 2011$ & -0.099 & 0.677 & 20 \\
$2011 / 2012$ & -0.074 & 0.758 & 20 \\
$2012 / 2013$ & -0.355 & 0.125 & 20 \\
$2013 / 2014$ & 0.047 & 0.845 & 20 \\
\hline
\end{tabular}

* Correlation is significant at the level of 0.01 (2-tailed).

Source: Author, based on: RZS, 2017

The values of the Spearman Coefficient show that the majority of the consecutive years and the sections have a low and weak, even negative, correlation of the ranks of the growth rates. This means that the directions of change in the economic structure are not stable, they do not continue year after year in the direction of the same sections, but the directions of changes are rather susceptible to variation. More importantly, no direction of changes has been obtained towards the sectors that have a higher level of productivity, and simultaneously the GVA growth rates, which enables a faster and greater total economic growth, which is unsustainable in the long run. This has an influence on the inability of singling out a sectionin the medium and long term which will be the driver of the growth and development of the economy of RS.

\section{CONCLUSION}

The economic structure of the Republic of Serbia consists of different activities, which the amount of the rates of economic growth and the speed of economic development depend on. The structural changes that have been achieved since 2001 have had an influence on the relative share, significance and location of certain sectors in the economy. The most significant share in the formation of the GDP and the creation of GVA is attributed to the sections of Manufacturing, Wholesale and retail trade; repair of motor vehicles and motorcycles, Real estate activities and Agriculture, forestry and fishing. Except for the section of Real estate activities, they also employ the largest number of workers.

The reduction in the share of the Manufacturing and Agriculture, forestry and fishing in the GDP and employment is a consequence of the inefficient transition process, the structural characteristics and tertiarization of the economy. We may agree upon the fact that this is the general characteristic and price of transition and structural changes, but we may not agree upon the role and significance of the overall real sector in the economic development of the Republic of Serbia as a developing country, whose GDP per capita is only 5,200 dollars.

It may be assessed that the structural changes in the economy of the Republic of Serbia are slow and belated. There are a small number of the sections whose growth rates are more dynamic and more propulsive, and whose changes are simultaneously characterized by a higher intensity. Also, the structural changes are not persistent and 
sustainable, their direction frequently changes between the sections, which thus has quite a small influence on changing the economic structure. This practically confirms the hypothesis that the level and speed of the development of the economy and the economic sectors of the Republic of Serbia are connected with the size, intensity and direction of changes in its structure.

It is a fact that structural changes are not fast and that they require time, but in order for the economy of the Republic of Serbia to achieve sustainable economic growth (4-5\%) and more noticeable employment growth in the period to come, and especially to become closer to the economies of the EU new member countries, it is necessary that serious and efficient changes in the structure of its economy should be made. The future development of the economy will directly depend on the speed of changes and the creation of a modern sectional economic structure, especially the development of a propulsive manufacturing structure, i.e. the development of the " 4.0 industries" or "networked industries".

This paper basically contributes to the critical evaluation of the development of the economy and the economic sectors from the aspect of the size, intensity and direction of structural changes. The results of this paper can be very beneficial when making decisions on future directions of development, more correctly to the choice of the basic and priority directions of the development of the economy of the Republic of Serbia. Yet, it is also significant to indicate the limitations of this paper, whose research was not dedicated to a comparison with the economies of other countries, and in which no more complex methodology and statistical analysis that would include a larger number of factors and their influence on structural changes were applied. Therefore, future research could be oriented towards the factors that influence the reallocation of employment and value added between the sectors, as well as to the examination of businessmen's attitudes and opinions with respect to the perspective of the development of certain economic sections.

The research has shown that structural changes in the economy are not efficiently implemented in the Republic of Serbia. For that reason, structural changes in the economy should be based on the main drivers and factors of structural changes, and today, they are innovations, research and development, knowledge and skills, although investments, other resources, offer and demand, institutions, relationships and agglomerations, externalities, international trade and globalization must not be neglected, either. These are also the important factors that can also start the reindustrialization of the economy of the Republic of Serbia.

The important message of the paper that could be useful to the Government is the importance of the implementation of an appropriate economic and industrial policy that encourages structural changes. Also, it is very important to know that the concept of complied and balanced development between the sectors must not be neglected.

\section{ENDNOTE}

1 The Statistical classification of economic activities in the European Community, abbreviated as NACE, is the classification of economic activities in the European Union (EU); the term NACE is derived from the French Nomenclature statistique des activités économiques dans la Communauté européenne.

\section{REFERENCES}

Baldwin, R., Braconier, H., \& Forslid, R. (2005). Multinationals, endogenous growth and technological spillovers: Theory and evidence. Review of International Economics, 13(5), 945-963. doi: 10.1111/j.14679396.2005.00546.x 
Bortis, H. (2000). Some considerations on structure and change. Structural change and economic dynamics, 11(1-2), 185-195. doi.org/10.1016/S0954-349X(99)00028-4

Chenery, H. B. (1975). The structuralist approach to development policy. The American Economic Review, 65(2), 310-316.

Cimoli, M., \& Katz, J. (2003). Structural reforms, technological gaps and economic development: A Latin American perspective. Industrial and corporate change, 12(2), 387-411. doi.org/10.1093/icc/12.2.387

Croitoru, A. (2012). Book review Schumpeter, J. A. 1934 (2008). The Theory of Economic Development: An Inquiry into Profits, Capital, Credit, Interest and the Business Cycle. Journal of Comparative Research in Anthropology and Sociology, 3(2), 137-148.

Jakopin, E. (2012). Post-crisis reallocation of growth factors. Economic Horizons, 14(2), 79-90. doi: 10.5937/ ekonhor1202077J

European Commission (EC). (2008). NACE Rev. 2 Statistical classification of economic activities in the European Community. European Commission, Eurostat, Brussels.

European Commission (EC). (2012). A Stronger European Industry for Growth and Economic Recovery. European Commission, Eurostat, Brussels.

Fagerberg, J. (2000). Technological progress, structural change and productivity growth: A comparative study. Structural change and economic dynamics, 11(4), 393-411. doi.org/10.1016/S0954-349X(00)00025-4

Lewis, W. A. (1954). Economic development with unlimited supplies of labour. The Manchester school, 22(2), 139-191. doi: 10.1111/j.1467-9957.1954.tb00021.x

Lin, Y. J. (2012). New Structural Economics: A Framework for Rethinking Development and Policy. Washington, USA: World Bank, 5.

Machlup, F. (1991). Economic semantics. New Jersey, USA: Transaction publishers.

Marjanović, V. (2010). Značaj i uticaj privredne strukture na privredni razvoj. Ekonomske teme, 48(3), 369-382.

Marjanović, V. (2015). Strukturne promene i strukturna transformacija u savremenoj razvojnoj ekonomiji. Ekonomske teme, 53(1), 65-84.
Mićić, V. (2016). Strukturne promene i konkurentnost prerađivačke industrije Republike Srbije, U: V. Marinković, V. Janjić, i V. Mićić, (Red.). Unapređenje konkurentnosti privrede Republike Srbije (str. 153-161). Kragujevac, Republika Srbija: Ekonomski fakultet Univerziteta u Kragujevcu.

Moore, J. H. (1978). A measure of structural change in output. Review of Income and Wealth, 24(1), 105-118. doi: 10.1111/j.1475-4991.1978.tb00034.x

Republički zavod za Statistiku (RZS). (2010). Klasifikacija delatnosti. Beograd, Republika Srbija: Republički zavod za Statistiku.

Republički zavod za statistiku (RZS). (2017). Statistička baza podataka. Beograd, Republika Srbija: Republički zavod za Statistiku.

Roman, Z. (1969). A note on measuring structural changes. Review of Income and Wealth, 15(3), 265-268. doi: 10.1111/ j.1475-4991.1969.tb00809.x

Rowthorn, R. E., \& Ramaswamy, R. (1997). Deindustrialization: Causes and implications. IMF Working Paper 97/42.

Savić, Lj., Bošković, G., \& Mićić, V. (2015). Structural changes in manufacturing industry at division level Serbia and new EU member states. Industrija, 43(4), 2545. doi: 10.5937/industrija43-8484

Syrquin, M. (2008). 4 Structural change and development. International Handbook of Development Economics, 1, 48.

Timmer, C. P., \& Akkus, S. (2008). The structural transformation as a pathway out of poverty: Analytics, empirics and politics. Working Paper, No. 150.

United Nations (UN). (2008). International Standard Industrial Classification of All Economic Activities. Revision 4, Statistical papers Series M, No. 4/Rev.4, United Nations Industrial Development Organization.

UNIDO. (2013). Industrial Development Report 2013, Sustaining Employment Growth: The Role of Manufacturing and Structural Change. United Nations Industrial Development Organization.

Upadhyaya, S., \& Yeganeh, S. M. (2015). Competitive Industrial Performance Report 2014. Working paper series, 12/2014, 10-11, United Nations Industrial Development Organization. 


\section{Received on $8^{\text {th }}$ April 2017, after two revisions, accepted for publication on $24^{\text {th }}$ April 2017. \\ Published online on $28^{\text {th }}$ April 2017.}

Vladimir Micic is an Associate Professor at the Faculty of Economics University of Kragujevac, the Republic of Serbia where he received his $\mathrm{PhD}$ degree. He teaches the subjects of Economics of Industry, Economic Development, and Economics of Growth and Development. His research interests include the relevant issues of the development of industry, industry policy, structural changes and economic development. 


\title{
EKONOMSKI RAZVOJ REPUBLIKE SRBIJE DETERMINISAN SEKTORSKOM STRUKTUROM PRIVREDE
}

\author{
Vladimir Mićić* \\ Ekonomski fakultet Univerziteta u Kragujevcu
}

\begin{abstract}
Iskustvo i dobra praksa pokazuju da je u cilju ostvarenja ekonomskog rasta i razvoja potrebno sprovoditi promene privredne strukture. One utiču na relativno učešće, mesto i ulogu pojedinih aktivnosti u privredi, i pokretač su održivog ekonomskog razvoja. Efikasne strukturne promene povezane su sa sposobnošću privrede da stvara propulzivnije ekonomske delatnosti. Predmet istraživanja ovog rada jeste utvrđivanje stepena determinisanosti ekonomskog razvoj Republike Srbije sektorskom strukturom privrede. Cilj istraživanja jeste da ukaže na adekvatnost veličine i doprinosa sektora stvaranju bruto dodate vrednosti i ukupnoj zaposlenosti, odnosno, uticaju veličine, intenziteta i pravaca promena između sektora na ekonomski razvoj. Rezultati istraživanja ukazuju da su dostignuti nivo razvoja i niske stope rasta privrede Republike Srbije posledica nedovoljno obuhvatnih i intenzivnih promena, promena koje kasne i nisu stabilne. Budući razvoj privrede direktno će zavisiti od brzine promena i stvaranja moderne sektorske privredne strukture, posebno razvoja propulzivne proizvodne strukture ili „industrija 4.0".
\end{abstract}

Ključne reči: ekonomski razvoj, strukturne promene, stopa ekonomskog rasta, zaposlenost, dodata vrednost

JEL Classification: L16, O11, O47, E24, H24

\section{UVOD}

Ekonomski razvoj je višedimenzionalan i kompleksan proces koji, pored ekonomskog rasta, obuhvata promene $\mathrm{u}$ strukturi privrede, kao i promene $\mathrm{u}$ resursima, institucijama, tehnologiji, procesima i brojne druge promene $u$ društvenom sistemu. Kod

* Korespondencija: V. Mićić, Ekonomski fakultet Univerziteta u Kragujevcu, Đ. Pucara 3, 34000 Kragujevac, Republika Srbija; e-mail: micicv@kg.ac.rs zemalja u razvoju, poput Republike Srbije (RS), strukturne promene su neophodne kako bi brže rastao bruto domaći proizvod (BDP) po glavi stanovnika. Praksa pokazuje da je u cilju ostvarenja održivog ekonomskog rasta i razvoja potrebno sprovoditi efikasne promene privredne strukture. One utiču na stvaranje propulzivnih aktivnosti, a rast BDP po glavi stanovnika, utiče da se realokacija radne snage i novostvorene vrednosti ostvaruje od aktivnosti intenzivnih radom i resursima, kao aktivnostima koje su više intenzivne znanjem i tehnologijom. 
Privredna struktura je faktor koji utiče na ekonomski rast i razvoj jedne nacionalne privrede, pa i RS. Stoga je predmet istraživanja ovog rada utvrđivanje stepena determinisanosti ekonomskog razvoja RS sektorskom strukturom privrede.

Cilj istraživanja jeste da ukaže na adekvatnost veličine i doprinosa sektora stvaranju bruto dodate vrednosti zaposlenosti, odnosno, uticaju veličine, intenziteta i pravaca promena između sektora na njihov i na ukupan ekonomski razvoj.

$\mathrm{U}$ skladu sa postavljenim predmetom i ciljem, $\mathrm{u}$ radu će biti testirana hipoteza da su nivo i brzina razvoja privrede i privrednih sektora RS povezani sa veličinom, intenzitetom i pravcem promena njene strukture.

U istraživanju će biti korišćeni sekundarni izvori podataka iz statističke baze Republičkog zavoda za statistiku (RZS) za stope rasta privrede i sektora, novostvorenu vrednost i ukupnu zaposlenost. U radu će pomoću standardne devijacije biti izmerena veličina strukturnih promena po sektorima. Intenzitet strukturnih promena sektora biće ispitan elastičnošću stopa rasta sektora. Primenom korelacije rangova stopa rasta sektora biće analiziran pravac strukturnih promena sektora privrede RS. Podaci će biti obrađeni i analizirani korišćenjem statističkog paketa SPSS.

Privreda se sastoji od aktivnosti (delatnosti) koje proizvode dobra koja su opipljiva ili dobra kojima se trguje i delatnosti koje proizvode dobra koja su neopipliiva ili dobra kojima se ne može trgovati. Sektori privrede definisani su prema proizvodnom principu ili statističkim klasifikacijama delatnosti Ujedinjenih nacija (UN) i Evropske unije (EU). Prema ovim klasifikacijama sve aktivnosti su svrstane na najvišem hijerarhiskom nivou $u$ sektore. $U$ ovom radu, podaci su agregirani na nivo od 21 delatnosti, po kome je privreda podeljena na ukupno 21 sektor.

Rad je strukturiran u sedam delova. U drugom i trećem delu dati su teorijski okviri analize privredne srukture, strukturnih promena i njihovih vrsta. Četvrti deo bavi se analizom osnovnih pokazatelja i merenja strukturnih promena. Peti deo pokazuje sektorsku strukturu nacionalne privrede i statističku klasifikaciju privrednih aktivnosti. Šesti deo sadrži rezultate istraživanja ili ulogu sektora privrede $\mathrm{u}$ ekonomskom rastu i razvoju RS. U sedmom delu prezentirani su zaključci i neke preporuke.

\section{PREGLED LITERATURE}

Privredna struktura je važan faktor koji utiče na ekonomski razvoj. Najčešće se pod privrednom strukturom podrazumeva celina sastavljena od delova koji su u određenim i međuzavisnim odnosima. Ta celina je promenljiva, a na promene utiču različiti faktori. Od nje zavisi struktura spoljne trgovine i platnog bilansa, a takođe je povezana sa tehničkim progresom, inovacijama, produktivnošću rada, zaposlenošću, inflacijom, privrednim sistemom, ekonomskom politikom, pa čak i specifičnim faktorima, kao što je kultura (Marjanović, 2010, 370).

Ukoliko se privreda posmatra kao celina sastavljena od delova, promena bilo koga dela ili načina povezanosti delova znači promenu privredne strukture. Ona je u neprekidnom procesu promena, ali te promene nisu brze i česte (Bortis, 2000, 186). Razlog za to su procesi tehnoloških promena i učenja koji su kumulativni i dugoročni (Upadhyaya \& Yeganeh, 2015, 10-11). Strukturne promene su usko povezane sa realokacijom i preraspodelom radne snage, ali i drugih faktora ekonomskog razvoja, između privrednih delatnosti.

Analiza privredne strukture i objašnjenja strukturnih promena su različita $u$ teorijama rasta $i$ modelima razvoja. J. A. Schumpeter je, razmatrajući ulogu različitih faktora razvoja, pre svega, ulogu preduzetnika i tehnoloških promena u ekonomskom razvoju, isticao da su inovacije i njihova primena kroz imitacije i dalja poboljšanja, osnovni pokretač koji vodi do strukturnih promena privrede (Croitoru, 2012, 137-148).

Dok su struktura i strukturne promene u centru pažnje klasične ekonomije, neoklasična ekonomija smatra da su strukturne promene rezultat razvoja tržišta i da nisu neophodan uslov ekonomskog razvoja. 
Najveću pažnju privrednoj strukturi, strukturnim promenama i obrascima razvoja poklanjaju teorije strukturnih promena (Lewis, 1954, 139-191; Chenery, 1975, 310-316). Usmerene su na mehanizam kojim nerazvijene privrede transformišu svoje privredne strukture od tradicionalne poljoprivrede ka industriji i raznovrsnim uslugama. One nastoje da pomoću neoklasične teorije cena, alokacije resursa i modela objasne kako dolazi do procesa transformacije privredne, industrijske i institucionalne strukture, kao i da što preciznije ekonometrijski kvantifikuju značaj strukturnih promena kao faktora ekonomskog rasta. Na osnovu njihovih istraživanja, brzina i obrazac rasta i razvoj privrede zavise od unutrašnjih faktora (akumulacije, ulaganja, korišćenja resura, veličine stanovništva, strukture tražnje, urbanizacije, institucionalnih ograničenja, promene socijalnoekonomskih faktora) i spoljnih faktora (od kojih su najznačajniji transfer tehnologije iz inostranstva i međunarodna trgovina).

Ekonomska kriza je krajem 60-tih i početkom 70-tih godina XX-og veka, koja je imala strukturni karakter, dovela do istraživanja uzroka i faktora, a posebno do veličine, stepena, brzine i pravaca strukturnih promena privrede, koja su za osnovu imala statističke serije stopa rasta sektora. Prema ovim istraživanjima, pod strukturnim promenama podrazumevaju se različiti aranžmani proizvodnih aktivnosti u privredi i različita distribucija proizvodnih faktora među različitim sektorima privrede, različitim delatnostima, regionima i vrstama proizvoda (Machlup, 1991, 76).

Kod endogenih teorija, centralno mesto u objašnjenju strukturnih promena i ekonomskog razvoja pripada tehnologiji (Baldwin, Braconier \& Forslid, 2005, 495). Takođe, one ispituju ulogu istraživanja i razvoja, infrastrukture, države, kao i institucionalnih faktora i organizacija. One uključuju i ulogu neopipljivih faktora u objašnjenju strukturnih promena, kao što su organizaciona struktura, menadžerske sposobnosti i kultura.

U ekonomskoj literaturi se smatra da strukturne promene utiču na relativno učešće, značaj i lokaciju pojedinih celina i delova u privredi, i da su važan pokretač ekonomskog razvoja (Syrquin, 2008, 48). Mada su uglavnom univerzalne, relacije, brzina i pravci strukturnih promena zavise od specifičnosti jedne privrede (Cimoli \& Katz, 2003, 387-411). Efikasne strukturne promene su važne za rast produktivnosti, kao i za efikasnu alokaciju resursa i korišćenje prednosti tehnologije i inovacija (Fagerberg, 2000, 393411). Kod zemalja u razvoju, strukturne promene su neophodne kako bi se obezbedio brži napredak u viši nivo razvoja (Lin, 2012, 5), odnosno, dostigle zemlje sa višim nivoom BDP po glavi stanovnika.

Danas se, pored glavnih pokretača strukturnih promena, inovacija i novih tehnologija, ističu i znanje, investicije, eksternalije, veštine, upoterba resursa, ponuda i tražnja, međunarodna trgovina, veze i aglomeracije, institucionalni okviri, globalizacija (UNIDO, 2013, 16).

Strukturne promene utiču na kreiranje ekonomske politike, kao svesnog uticaja države na ostvarivanje određenih razvojnih ciljeva. Ekonomska politika može uticati, pozitivno ili negativno, na promene $\mathrm{u}$ privrednoj strukturi, približavajući je ili udaljavajući od njenog optimuma (Marjanović, 2015, 67). Zbog toga je važna i sposobnost države da adekvatnom ekonomskom politikom oblikuje i utiče na strukturu privrede i strukturu pojedinih sektora, tj. da u skladu sa raspoloživim faktorima na kojima počiva razvoj, strukturne promene sprovodi efikasno, kontinuirano i aktivno (Mićić, 2016, 153-161).

U teoriji i praksi ekonomskog razvoja posebno se izdvajaju tri osnovne vrste strukturnih promena: industrijalizacija, deindustrijalizacija, i reindustrijalizacija.

Tokom procesa razvoja industrije, menjanje načina proizvodnje, u znatnoj meri, uslovljeno je krupnim promenama i tehničkim i tehnološkim inovacijama, tačnije industrijskim revolucijama ili pronalascima i usavršavanjem novih proizvoda, mašina i tehnologija. Prvu industrijsku revoluciju pokrenula je parna mašina, drugu električna energija i pokretne trake, a treću elektronika, računari i robotika. Novonastajuća, 
četvrta industrijska revolucija je globalnog karaktera i počiva na razvoju „industrija $4.0^{\prime \prime}$ ili umreženih industrija. Usled ubrzanog ciklusa tehničkih inovacija ona utiče na sve učesnike $u$ lancu industrijske proizvodnje i menja strukturu industrije i privrede. Zasniva se na nizu novih trendova i tehnologija, pre svega, veštačkoj inteligenciji, znanju i novim generacijama digitalnih tehnologija i digitalne infrastrukture.

Industrijalizacija obuhvata kompleks strukturnih promena, nastalih usled tehničkih inovacija, kojima se uvećava učeće industrije u stvaranju BDP-a i zaposlenosti, uz istovremeno kontinualno smanjenje učeša poljoprivrede i rast učeća sektora usluga. Praksa je pokazala da je industrijalizacija u nerazvijenim zemljama, u kojima dominira agrarna struktura, dovela do ekonomskog razvoja i promene privredne strukture. U svim fazama ekonomskog razvoja industrija dominantno utiče na privrednu strukturu, te se i druge dve vrste strukturnih promena, reindustrijalizacija i deindustrijalizacija, dovode u vezu sa tehničkim inovacijama i industrijskim razvojem. Ovi procesi i vrste strukturnih promena su $\mathrm{u}$ istovremeni i u uzročno-posledičnoj su vezi.

Deindustrijalizacija je proces strukturnih promena čija karakteristika je smanjenje učešća industrije i rast učešća sektora usluga u BDP-u i zaposlenosti. Reč je o dugoročnom procesu koji se donekle razlikuje između zemalja (Timmer \& Akkus, 2008, 7). Zajedničko obeležje ovog procesa je korelacija između nivoa BDP-a po stanovniku, sektorskog doprinosa stvaranju BDP-a, dodate vrednosti, distribucije zaposlenosti i produktivnosti rada. Deindustrijalizacijom dolazi do tercijarizacije privredne strukture, zahvaljujući snažnom razvoju sektora usluga.

Mora se praviti razlika između deindustrijalizacije kao pozitivnog i negativnog procesa (Rowthorn \& Ramaswamy, 1997, 1-2). U pozitivnom smislu, ona označava zrelost industrije čija proizvodnja je bazirana na nauci, znanju i tehničkim inovacijama. Dominantno učešće imaju grane visoke tehnološke intenzivnosti i visokog intenziteta korišćenja radnih veština i znanja, čime se gubi identitet klasične industrijske strukture. U negativnom smislu, ona ima za rezultat loše ekonomske performanse privrede. Najčešce je uzrokovana pogrešnom strategijom razvoja industrije $\mathrm{u}$ presudnim fazama njenog razvoja.

Reindustrijalizacija se vezuje za promenu razvojne paradigme, prema kojoj uspešan razvoj nije $u$ posedovanju prirodnih resursa i kapitala, već zavisi od tehnologije, inovacija, istraživanja, znanja i kvaliteta radne snage. Danas su ovi faktori osnova reindustrijalizacije, nastanka modernih, tehnološki novih, sofisticiranih, znanjem intenzivnih, ekološki odgovornih i energetski efikasnih industrija koje zapošljavaju visoko kvalifikovanu radnu snagu. Ubrzano se razvijaju i koriste nove tehnologije, bazirane na nanotehnologijama, mikroelektronici, robotici, 3-D procesu štampe, biotehnologiji i genetskom inženjeringu, novim materijalima, ekološkim automobilima i vozilima, ekološkom transportu, pametnim mrežama za prenos energije i sl.

Obrazovanje, istraživanje i inovacije su temelji reindustrijalizacije i razvoja jake, dinamične i održive industrijske baze (European Commission, 2012, 3), koja doprinosi strukturnim promenama i održivom ekonomskom rastu, stvaranju novih radnih mesta, ekološkoj efikasnosti, razvoju novih proizvoda sa visokom dodatom vrednošću i stvaranju ekonomije zasnovane na znanju. Reindustrijalizacija, pored direktnog doprinosa rastu industrijske produktivnosti, utiče na rast produktivnosti drugih sektora, posebno sektora usluga, i to putem obima ulaganja u nove tehnologije. Preciznije, ona je u centru novog modela ekonomskog rasta i razvoja većeg broja visoko razvijenih i brzorastućih privreda.

\section{MERENJE STRUKTURNIH PROMENA I STATISTIČKA KLASIFIKACIJA PRIVREDNIH AKTIVNOSTI}

Pokazatelji strukturnih promena su brojni, a najčešće se koriste pokazatelji koji mere promene sektorske strukture privrede $\mathrm{u}$ pogledu proizvodnje, zaposlenosti, dodate vrednosti, izvoza, znanja, inovacija, tehnologije i investicija. Prilikom 
kvantitativne analize strukturnih promena privrede po sektorima najčešće se koriste podaci o učešću pojedinih sektora u BDP-u, bruto dodatoj vrednosti (BDV) i zaposlenosti.

Veličina strukturnih promena po sektorima može se meriti standardnom devijacije stopa rasta tih sektora. Standardna devijacija stopa rasta po sektorima je direktno proporcionalna disperziji stopa rasta sektora i strukturnim promenama između tih sektora. Veća disperzija pokazuje da su strukturne promene veće, dok manja disperzija znači da su strukturne promene manje (Savić, Bošković \& Mićić, 2015, 30).

Za analizu intenziteta strukturnih promena mogu se koriste dva pristupa. Kod prvog pristupa intenzitet strukturnih promena na nivou sektora se računa na osnovu relativnih stopa rasta svakog sektora. Te stope se dobijaju kao $\mathrm{Q}_{\mathrm{i} 1} / \mathrm{Q}_{\mathrm{i} 0}: \mathrm{P}_{1} / \mathrm{P}_{0}$ ili kao $\left(\left(\mathrm{Q}_{\mathrm{i} 1} / \mathrm{P}_{1}: \mathrm{Q}_{\mathrm{i} 0} / \mathrm{P}_{0}\right)-1\right) \times 100$. U prvom slučaju utvrđuje se promena veličine pojedinačnog sektora $Q_{i}$ sa agregatnom veličinom $\mathrm{P}$, a u drugom slučaju učešće pojedinačnog segmenta strukture $u$ ukupnoj veličini. Pokazatelj strukturnih promena dobija se kao aritmetički prosek zbira, koji je ponderisan učešćem relativnih stopa rasta $\mathrm{u}$ ukupnom izrazu. Drugi pristup, za analizu intenziteta strukturnih promena na nivou sektora koristi elastičnost stopa rasta. One se računaju kada se podeli stopa rasta posmatranog sektora i stope rasta privrede (Roman, 1969, 265-268). Ukoliko se dobije koeficijent veći od jedan to znači da sektor povećava svoje učešće, a time se povećava i njihova uloga i značaj u jednoj privredi.

Uz ove pokazatelje često se koristi korelacija rangova stopa rasta aktivnosti. Njom se analiziraju pravaci strukturnih promena tih sektora, a pravac strukturnih promena pokazuje Spearman-ov koeficijent korelacije rangova stopa rasta sektora za uzastopne parove godina (Savić et al, 2015, 31). Korelacija rangova je visoka ako se promene konstatno odvijaju u korist istih sektora, a niska je ako se pravci promena često menjaju između sektora privrede.

Takođe, privredna struktura $u$ jednoj godini može biti iskazana i kao n-dimenzionalni vektor. Kordinate tog vektora predstavljaju učešća pojedinih sektora u agregatnoj veličini, kao što je BDP. Strukturne promene se ogledaju u promeni kordinata tih vektora. Posmatrano dinamički, razlike između strukture vektora $u$ pojedinim godinama mogu se izraziti kosinusom između tih vektora (Moore, 1978, 107).

Različite privredne aktivnosti proizvodnje i usluga grupišu se $u$ privredne sektore. Sektori se mogu podeliti i grupisati prema većem broju kriterijuma, a najčešće se koriste faze $\mathrm{u}$ proizvodnom lancu, prema kojem se grupišu u primarni, sekundarni i tercijarni. Tercijarni sektor je vremenom postao najheterogeniji, zato što se najviše proširio i izdiferencirao. Zato postoji težnja da se tercijarni sektor dalje diferencira na kvartarni sektor, u privredno i industrijski najrazvijenim zemljama.

Pošto privredu mogu činiti različite, dinamične i heterogene aktivnosti, u ekonomskim analizama, danas se, zbog vremenske i prostorne uporedivosti podataka, načešće koristi statistička klasifikacija privrede i privrednih aktivnosti prema proizvodnom principu. Za potrebe ovoga rada biće korišćenja statistička klasifikacija ekonomskih aktivnosti EU (European Commission, 2008, 11-17), koja je izvedena iz industrijske klasifikacije ekonomskih aktivnosti UN.

Zvanična statistička podela svih privrednih aktivnosti izvršena je prema Međunarodnoj statističkoj klasifikaciji od strane UN (United Nation, 2008, 1-21). Njen naziv je Međunarodna standardna industrijska klasifikacija ekonomskih aktivnosti (United Nation's International Standard Industrial Classificationa of all Economic Activities - ISIC). ISIC najvećim delom prati standardna klasifikacija EU $\left(N A C E^{1}\right)$. Prema NACE i ISIC klasifikacijama sve aktivnosti svrstane su na najvišem hijerarhiskom nivou u sektore.

NACE i ISIC obezbeđuju okvir za prikupljanje i prikazivanje velikog obima statističkih podataka prema ekonomskim delatnostima kako u oblasti ekonomskih statistika (proizvodnja, zaposlenost, nacionalni računi), tako i u drugim statističkim oblastima. NACE je izvedena i predstavlja deo ISIC klasifikacije. Kategorije na svim nivoima NACE su definisane da budu identične sa ISIC kategorijama. ISIC i NACE imaju isti broj kategorija na najvišem nivou, ali je NACE detaljnija na nižim nivoima. Prvi i drugi nivo ISIC, Revizija 4, odnosno sektori i 
oblasti privrede, su identične sektorima i oblastima NACE, Revizija 2. Treći i četvrti nivo, odnosno, grane i grupe podeljene su detaljnije u NACE, Reviziji 2, prema evropskim potrebama. Cilj detaljnijih podela u NACE, Revizija 2, jeste da se dobije klasifikacija koja je primerenija strukturama ekonomija članica EU.

Od 2011, u RS se primenjuje Klasifikacija delatnosti iz 2010, u okviru procesa usklađivanja sa standardima EU i Evropskog statističkog sistema. Nova Klasifikacija delatnosti je bez izmena preuzeta standardna klasifikacija delatnosti EU iz 2008. (RZS, 2010, 4).

\section{ULOGA SEKTORA PRIVREDE U EKONOMSKOM RASTU I RAZVOJU REPUBLIKE SRBIJE}

Struktura privrede RS po sektorima, kao i promena te strukture, prikazana je $\mathrm{u}$ Tabeli 1. Posmatrano po sektorima, najznačajnije učešće $u$ formiranju BDP-a, odnosno, najveći doprinos stvaranju BDV-a u 2014, imaju sektori Prerađivačke industrije (C) 15,6\%, Trgovine na veliko i malo i popravki motornih vozila i motocikala (G) 10,2\%, Poslovanja nekretninama 8,9\% (L) i Poljoprivrede, šumarstva i ribolova 6,8\% (A).

Pored visokog učešća sektora Prerađivačke industrije i Poljoprivrede, šumarstva i ribolova u stvaranju BDP-a, privredna stuktura RS izmenjena je od 2001. u korist uslužnog sektora, koji ima najveće sektorsko učešće. Dinamičan rast uslužnog sektora u BDP-a do 2008, ostvaren je zahvaljujući povećanju učešća, pre svega, sektora Trgovine na veliko i malo i popravki motornih vozila i motocikala, Informacija i komunikacija, Finansijskih aktivnosti i osiguranja i Stručne, naučne, inovacione i tehničke delatnosti. Ovi sektori su propulzivnost i više stope rasta zasnivali na investicijama, posebno $\mathrm{u}$ telekomunikacijama, liberalizaciji uvoza, rastu lične potrošnje, privatizaciji i restrukturiranju bankarskog i finansijskog sektora. Rast učešća sektora usluga, uz smanjenje udela realnog sektora, posebno prerađivačke industrije i poljoprivrede u proizvodnji i zaposlenosti, uobičajena su obeležja tranzicionog procesa i tercijarizacije privrede.
Tabela 1 Struktura BDP-a Republike Srbije

\begin{tabular}{|c|c|c|c|c|}
\hline Sektor & 2001. & 2009. & 2014. & ${ }^{*}+1-$ \\
\hline A & 18,2 & 8,0 & 6,8 & $-11,4$ \\
\hline B & 1,2 & 1,3 & 1,0 & $-0,2$ \\
\hline$C$ & 21,7 & 13,6 & 15,6 & $-6,1$ \\
\hline D & 0,6 & 3,2 & 3,7 & 3,1 \\
\hline E & 0,8 & 1,1 & 1,1 & 0,3 \\
\hline $\mathrm{F}$ & 3,5 & 4,1 & 4,5 & 1,0 \\
\hline$G$ & 7,6 & 9,5 & 10,2 & 2,6 \\
\hline $\mathrm{H}$ & 3,7 & 4,7 & 4,4 & 0,7 \\
\hline I & 0,9 & 1,0 & 1,1 & 0,2 \\
\hline $\mathrm{J}$ & 3,3 & 4,2 & 4,4 & 1,1 \\
\hline K & 1,8 & 3,1 & 3,0 & 1,2 \\
\hline $\mathrm{L}$ & 13,2 & 10,9 & 8,9 & $-4,3$ \\
\hline M & 1,8 & 3,6 & 3,3 & 1,5 \\
\hline $\mathrm{N}$ & 0,9 & 1,4 & 1,4 & 0,5 \\
\hline 0 & 6,4 & 3,3 & 3,5 & $-2,9$ \\
\hline$P$ & 2,3 & 4,4 & 2,9 & 0,6 \\
\hline Q & 3,7 & 5,5 & 4,5 & 0,8 \\
\hline $\mathrm{R}$ & 0,7 & 1,3 & 1,0 & 0,3 \\
\hline$S$ & 0,6 & 1,4 & 1,4 & 0,8 \\
\hline$T$ & 0,1 & 0,1 & 0,1 & 0,0 \\
\hline U & - & - & - & - \\
\hline BDV & 93,1 & 85,8 & 82,8 & $-10,3$ \\
\hline $\begin{array}{l}\text { Porezi na } \\
\text { proizvode }\end{array}$ & 6,2 & 13,5 & 17,8 & 11,6 \\
\hline $\begin{array}{l}\text { Subvencije na } \\
\text { proizvode }\end{array}$ & 0,7 & 0,7 & 0,6 & $-0,1$ \\
\hline BDP & 100,0 & 100,0 & 100,0 & - \\
\hline
\end{tabular}

* +/- 2015. u odnosu na 2001.

Izvor: Autor, na osnovu: RZS, 2017

Broj radnika je neznatno povećan u privredi RS, 2015. u odnosu na 2010. (Tabela 2). Istovremeno, broj zaposlenih u sektorima Prerađivačke industrije (C) i Smeštaja i uslugama pripremanja hrane (I), smanjen je za po 16.000, dok je u sektoru Trgovine na veliko i malo i popravki motornih vozila i motocikala (G) smanjen za preko 20.000 radnika. I pored toga, sektorske promene zaposlenih karakteriše sve veći broj i procenat zaposlenih u sektoru usluga.

Ipak, uslužni sektor, od 2010, ne može da stvori dovoljno novih radnih mesta, posebno zbog posledica Globalne ekonomske krize, kako bi se nadoknadio 
pad zaposlenosti $\mathrm{u}$ industriji. Zbog toga se deo radne snage iz industrije realocira u primarni sektor, posebno u poljoprivredu. Takođe, činjenica je da realokacija radne snage unutar sektora još uvek dominira nad realokacijom između sektora. Najveći problem, kao rezultat neefikasnih strukturnih promena, predstavlja visoka stopa nezaposlenosti, što iz socijalnog i razvojnog ugla ima posebnu težinu (Jakopin, 2012, 86).

Tabela 2 Ukupan broj i struktura zaposlenih, 2010-2015.

\begin{tabular}{c|rrrrr}
\hline Sektor & \multicolumn{1}{|c}{2010.} & \multicolumn{1}{c}{$\%$} & \multicolumn{1}{c}{2015.} & \multicolumn{1}{c}{$\%$} & \multicolumn{1}{c}{+ - $^{*}$} \\
\hline A-U & 2.396 .244 & 100,00 & 2.459 .048 & 100,00 & 62.804 \\
\hline A & 532.969 & 22,24 & 538.040 & 21,88 & 5.071 \\
B & 23.316 & 0,97 & 29.198 & 1,19 & 5.882 \\
C & 401.711 & 16,76 & 385.369 & 15,67 & -16.342 \\
D & 36.293 & 1,51 & 37.386 & 1,52 & 1.093 \\
E & 41.097 & 1,72 & 35.548 & 1,45 & -5.549 \\
F & 120.689 & 5,04 & 120.476 & 4,90 & -213 \\
G & 326.283 & 13,62 & 305.493 & 12,42 & -20.790 \\
H & 125.563 & 5,24 & 121.550 & 4,94 & -4.013 \\
I & 71.610 & 2,99 & 55.442 & 2,25 & -16.168 \\
J & 47.682 & 1,99 & 49.253 & 2,00 & 1.571 \\
K & 44.852 & 1,87 & 40.839 & 1,66 & -4.013 \\
L & 3.268 & 0,14 & 2.467 & 0,10 & -801 \\
M & 57.053 & 2,38 & 61.701 & 2,51 & 4.648 \\
N & 37.694 & 1,57 & 56.725 & 2,31 & 19.031 \\
O & 120.459 & 5,03 & 138.827 & 5,65 & 18.368 \\
P & 159.381 & 6,65 & 164.215 & 6,68 & 4.834 \\
Q & 157.137 & 6,56 & 141.713 & 5,76 & -15.424 \\
R & 36.964 & 1,54 & 45.794 & 1,86 & 8.830 \\
S & 47.627 & 1,99 & 49.499 & 2,01 & 1.872 \\
T & 3.770 & 0,16 & 78.810 & 3,20 & 75.040 \\
U & 825 & 0,03 & 705 & 0,03 & -120 \\
\hline & & & & &
\end{tabular}

* +/- 2015. u odnosu na 2010.

Izvor: Autor, na osnovu: RZS, 2017
Prema proizvodnom principu, broj zaposlenih $\mathrm{u}$ sektorima Rudarstva (B), Prerađivačke industrije (C) i Snabdevanja električnom energijom, gasom i parom (D) je oko 452.000, dok je broj zaposlenih u sektoru Poljoprivrede, šumarstva i ribolova (A) oko 538.000 zaposlenih u 2015. Istovremeno, relativno učešće zaposlenih u tri sektora industrije (B, C i D) jeste oko $18,4 \%$ u ukupno zaposlenim, dok je relativno učešće zaposlenih u sektoru Poljoprivrede, šumarstva i ribolova 21,9\%. Ovo pokazuje kakav je nivo ekonomskog razvoja, kakva je realokacija radne snage, koliko su neefikasne strukturne promene privrede, $\mathrm{u}$ kakvom se stanju nalazi industrija, i što je najbitnije, kakva je i kolika njena uloga u ekonomskom razvoju RS.

Podaci pokazuju da je od 2008. jedino udeo tercijarnog sektora beležio rast zaposlenosti i to sa $48,7 \%$ na $53,4 \%$. Udeo sekundarnog sektora smanjen je sa $25 \%$ na $23,5 \%$, dok je primarni sektor smanjio učešće sa $26,3 \%$ na $23,1 \%$.

Može se oceniti da, u poređenju sa prosekom EU gde je učešće zaposlenih u primarnom sektoru oko 5\%, sekundarnom sektoru oko $17 \%$ i tercijarnom sektoru oko $78 \%$, sektorska struktura zaposlenih u privredi RS značajno odstupa.

Analiza na nivou sektora privrede RS, mereno učešćem u BDP-u i zaposlenosti, pokazuje da većim strukturnim promenama između sektora odgovara veća standardna devijacija i disprezija stopa rasta sektora. To potvrđuje standardna devijacija kretanja stopa rasta sektora privrede po godinama. Veća disperzija znači da je standardna devijacija veća, i suprotno (Tabela 3).

Prethodna analiza na nivou sektora privrede RS, kvantifikovana učešćem u BDP-u i zaposlenosti, pokazuje da većim strukturnim promenama između sektora odgovaraju veće fluktuacije stopa rasta tih sektora. Ovo potvrđuje i standardna devijacija, kao i disperzija stopa rasta po sektorima, koje su direktno proporcionalne fluktuaciji stopa rasta posmatranih sektora. 
Tabela 3 Standardna devijacija i deskriptivna statistika, 2001-2014.

\begin{tabular}{c|cccc}
\hline Sektor & Minimum & Maximum & Prosek & $\begin{array}{c}\text { Standardna } \\
\text { devijacija }\end{array}$ \\
\hline A-U & $-3,6$ & 8,8 & 2,414 & 0,8630 \\
\hline A & $-17,3$ & 20,9 & 2,086 & 2,9431 \\
B & $-23,3$ & 9,0 & $-0,571$ & 2,2400 \\
C & $-15,8$ & 6,4 & 0,329 & 1,4912 \\
D & $-28,8$ & 13,0 & 0,014 & 2,6227 \\
E & $-12,6$ & 3,7 & $-1,064$ & 1,1986 \\
F & $-19,7$ & 36,1 & 4,607 & 3,7874 \\
G & $-7,5$ & 19,0 & 6,929 & 2,3586 \\
H & $-10,0$ & 11,3 & 3,679 & 1,4974 \\
I & $-10,0$ & 7,9 & $-1,471$ & 1,1660 \\
J & $-3,9$ & 27,1 & 11,721 & 2,4923 \\
K & $-9,5$ & 17,8 & 4,121 & 2,1327 \\
L & $-1,3$ & 4,1 & 1,593 & 0,4035 \\
M & $-7,5$ & 10,2 & 2,979 & 1,1835 \\
N & $-4,3$ & 23,0 & 5,550 & 2,1389 \\
O & $-2,9$ & 4,7 & 1,229 & 0,6103 \\
P & $-3,4$ & 1,4 & $-0,450$ & 0,4058 \\
Q & $-3,0$ & 2,8 & 0,364 & 0,3807 \\
R & $-10,2$ & 10,1 & 2,179 & 1,3346 \\
S & $-12,0$ & 12,4 & 0,800 & 1,6699 \\
T & $-6,7$ & 8,5 & 2,071 & 1,1554 \\
U & n.p. & $n . p$. & $n . p$. & n.p. \\
\hline P - & & &
\end{tabular}

n.p. - nema podataka

Izvor: Autor, na osnovu: RZS, 2017

Ono što nije dobro za strukturne promene, jeste da sektori čije je učešće veće i čije stope rasta beleže veće fluktuacije nemaju rastuće učešće u strukturi i ne pokreću promene privrede. Odnosno, standardna devijacija pokazuje da su u njima strukturne promene opadajuća, a ne rastuća funkcija stopa rasta. Najmanje strukturne promene ostvarene su u sektorima Zdravstvene i socijalne zaštite (Q), Obrazovanja (P) i Poslovanja nekretninama (L), dok su najveće promene zabeležili sektori Građevinarstva (G), Snabdevanja vodom, upravljanja otpadnim vodama i kontrolisanja uklanjanja otpada (E) i Poljoprivrede, šumarstva i ribolova (A). Ostali sektori beleže umerenije standardne devijacije stopa rasta po godinama.

Iskustva ekonomskog razvoja drugih zemalja pokazuju da propulzivnije, više i održive stope rasta pojedinih sektora privrede utiču na pravac razvoja i stvaranje moderne privredne strukture ekonomije. Kretanje maksimalnih i minimalnih stopa rasta sektora privrede RS ovo ne potvrđuje. Sektori koji su zabeležili najviše stope rasta, zabeležili su i najviše stope pada, što je posebno slučaj kod realnih sektora privrede, koji proizvode razmenljiva dobra (A-F). Nešto bolja situacija je kod nekih uslužnih sektora (G-R).

Za dinamičniju proizvodnu strukturu u RS neophodno je efikasno sprovođenje ekonomske politike, pre svega, agrarne i industrijske politike, posebno kod pokretanja ključnih faktora strukturnih promena. Ovo se nije desilo tako da stope rasta nisu mogle biti više, pa čak ni stope rasta nekih tradicionalnih sektora privrede i aktivnosti, kao što su poljoprivreda i prehrambena industrija (Savić et al, 2015, 25-45)

Intenzitet strukturnih promena sektora privrede RS ispitan je putem elastičnosti stopa rasta sektora. Kod sektora gde je izračunati koeficijent elastičnosti veći od jedan dolazi do povećanja njihovog učešće $u$ BDV-u, čime se povećava i njihova važnost i doprinos u privrednom razvoju RS (Slika 1).

Istraživanje intenziteta promena pokazuje da su one najviše kod Informacija i komunikacija (J), Trgovine na veliko i malo i popravke motornih vozila i motocikala (G), Administrativnih i pomoćnih uslužnih delatnosti (N), Građevinarstva (F) i Finansijskih aktivnosti i osiguranja (K). Ovu činjenicu potvrđuje ne samo elastičnost stopa rasta posmatranih sektora, već i njihova prosečna stopa rasta posle 2001. Na intenzitet 
strukturnih promena ovih sektora uticala je privatizacija i veličina investicija u tim sektorima.

Spirmanov koeficijent korelacije rangova između stopa rasta za uzastopne parove godina, za 20 sektora privrede RS, pokazuje pravac strukturnih promena između tih sektora (Tabela 4). Za 21 sektor, Delatnost eksteritorijalnih organizacija i tela (U), ne postoje uporedivi podaci u posmatranom periodu.

Vrednosti Spirmanovog koeficijenta pokazuju da se za većinu uzastopnih godina i sektora radi o niskoj i slaboj, pa čak i negativnoj korelaciji rangova stopa rasta. To znači da pravci promene privredne strukture nisu stabilni, ne nastavljaju se godinu za godinom u pravcu istih sektora, već su smerovi promena podložni variranju. Još bitnije, nije ostvaren pravac promena prema sektorima koji imaju viši nivo produktivnosi, a time i stope rasta BDV-a, čime se postiže brži i viši ukupan privredni rast, što je dugoročno neodrživo. Ovo utiče na to da se $u$ srednjem i dugom roku ne može izdvojiti sektor koji će biti pokretač rasta i razvoja privrede RS.
Tabela 4 Spirmanov koeficijent korelacije rangova, 2001-2014.

\begin{tabular}{c|ccc}
\hline $\begin{array}{c}\text { Uzastopni } \\
\text { parovi } \\
\text { godina }\end{array}$ & $\begin{array}{c}\text { Koficijent } \\
\text { korelacije }\end{array}$ & $\begin{array}{c}\text { Sig. } \\
\text { (2-tailed) }\end{array}$ & $\mathrm{N}$ \\
\hline $2001 / 2002$ & 0,277 & 0,238 & 20 \\
$2002 / 2003$ & 0,295 & 0,207 & 20 \\
$2003 / 2004$ & 0,011 & 0,965 & 20 \\
$2004 / 2005$ & 0,427 & 0,060 & 20 \\
$2005 / 2006$ & $0,614^{*}$ & 0,004 & 20 \\
$2006 / 2007$ & 0,441 & 0,052 & 20 \\
$2007 / 2008$ & 0,352 & 0,128 & 20 \\
$2008 / 2009$ & $0,611^{*}$ & 0,004 & 20 \\
$2009 / 2010$ & 0,395 & 0,084 & 20 \\
$2010 / 2011$ & $-0,099$ & 0,677 & 20 \\
$2011 / 2012$ & $-0,074$ & 0,758 & 20 \\
$2012 / 2013$ & $-0,355$ & 0,125 & 20 \\
$2013 / 2014$ & 0,047 & 0,845 & 20 \\
\hline
\end{tabular}

${ }^{*}$ Korelacija je značajna na nivou 0.01 (2-tailed). Izvor: Autor, na osnovu: RZS, 2017

\section{Elastičnost stopa rasta}

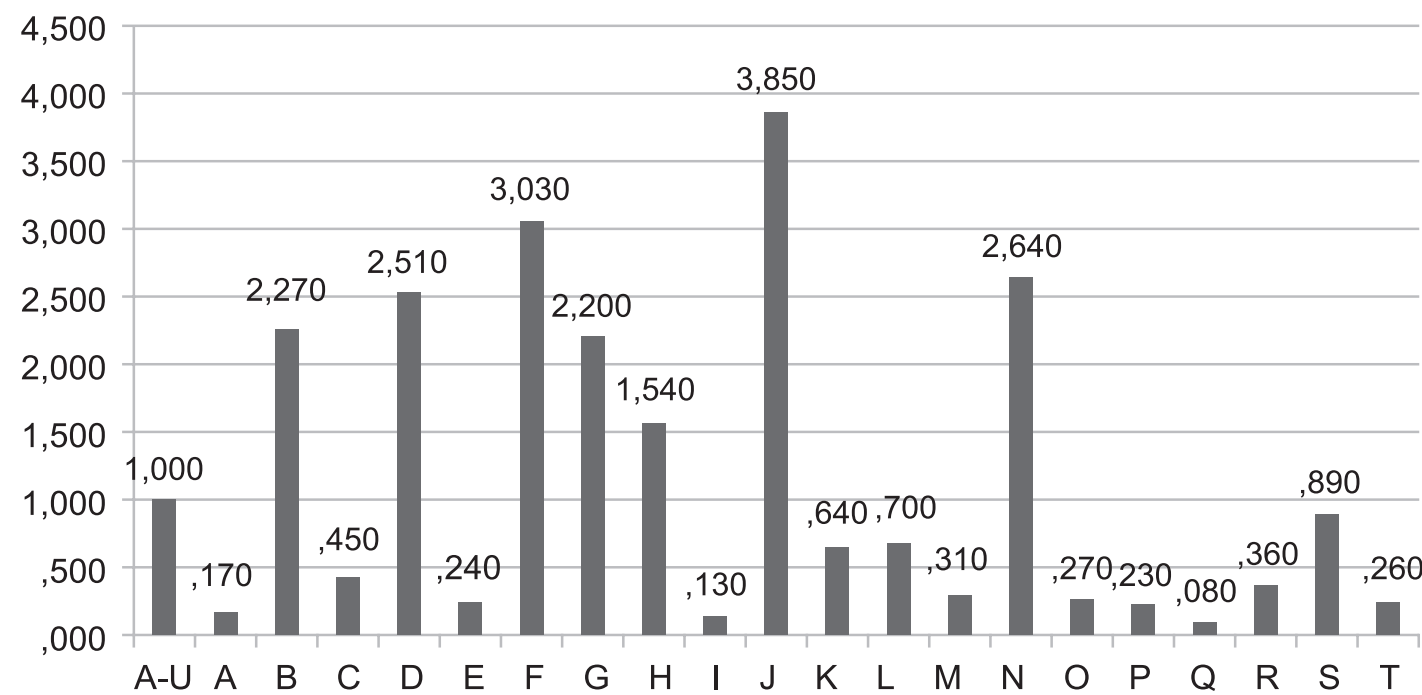

Slika 1 Intenzitet strukturnih promena, 2001-2014. 


\section{ZAKLJUČAK}

Privredna struktura Republike Srbije sastavljena je od različitih delatnosti od kojih zavisi visina stopa ekonomskog rasta i brzina ekonomskog razvoja. Ostvarene strukturne promene od 2001. uticale su na relativno učešće, značaj i lokaciju pojedinih sektora u privredi. Najznačajnije učešće $u$ formiranju BDP-a i stvaranju BDV-a imaju sektori Prerađivačke industrije, Trgovina na veliko i malo i popravke motornih vozila i motocikala, Poslovanja nekretninama i Poljoprivrede, šumarstva i ribolova. Izuzev sektora Poslovanja nekretninama, oni upošljavaju i najveći broj radnika.

Smanjenje učešća Prerađivačke industrije i Poljoprivrede, šumarstva i ribolova u BDP-u i zaposlenosti posledica je neefikasnog tranzicionog procesa, strukturnih obeležja i tercijarizacije privrede. Možemo se složiti sa činjenicom da je ovo opšta karakteristika i cena tranzicije i strukturnih promena, ali se ne možemo složiti sa ulogom i značajem celokupnog realnog sektora u ekonomskom razvoju $\mathrm{RS}$, kao zemlje koja se nalazi u razvoju i ima BDP po glavi stanovnika od svega 5.200 dolara.

Može se oceniti da su strukturne promene u privredi RS spore i da kasne. Mali je broj sektora koji imaju dinamičnije i propulzivnije stope rasta, a time i veći intenzitet promena. Takođe, strukturne promene nisu postojane i održive, njihov pravac se često menja između sektora, čim se malo utiče na menjanje privredne strukture. Praktično, ovo potvrđuje hipotezu da su nivo i brzina razvoja privrede $\mathrm{i}$ privrednih sektora RS povezani sa veličinom, intenzitetom i pravcem promena njene sektorske strukture.

Činjenica je da strukturne promene nisu brze i da zahtevaju vreme, ali da bi privreda RS ostvarila održivi privredni rast (4-5\%), i osetniji rast zaposlenosti u narednom periodu, a posebno da bi se približila ekonomijama novih članica EU, neophodne su ozbiljne i efikasne promene strukture privredne. Budući razvoj privrede direktno će zavisiti od brzine promena i stvaranja moderne sektorske privredne strukture, posebno razvoja propulzivne proizvodne strukture, odnosno, razvoja „industrija $4.0^{\prime \prime}$ ili umreženih industrija.

Osnovni doprinos ovoga rada jeste u kritičkoj evaluaciji razvoja privrede i privrednih sektora sa aspekta veličine, intenziteta i pravca strukturnih promena. Rezultati ovog istraživanja mogu biti veoma korisni prilikom donošenja odluka o budućim pravcima razvoja, tačnije, izboru osnovnih i prioritetnih pravaca razvoja privrede RS. Ipak, značajno je ukazati i na ograničenja ovoga rada, čije istraživanje se nije bavilo komparacijom sa ekonomijama drugih zemalja, i u radu nije primenjena kompleksnija metodologija i statistička analiza kojom bi se obuhvatio veći broj faktora i njihov uticaj na strukturne promene. Stoga bi buduće istraživanje moglo biti usmereno na faktore koji utiču na realokaciju zaposlenosti i dodate vrednosti između sektora, kao i na isptivanje stavova i mišljenja privrednika u pogledu perspektive razvoja pojedinih privrednih sektora.

Istraživanje je pokazalo da se u Republici Srbiji ne sprovode efikasno strukturne promene privrede. Zbog toga, strukturne promene privrede treba bazirati na glavnim pokretačima i faktorima strukturnih promena, a danas su to inovacije, istraživanje i razvoj, znanje i veštine, ali se ne smeju zanemariti ni investicije, drugi resursi, ponuda i tražnja, institucije, veze i aglomeracije, eksternalije, međunarodna trgovina i globalizacija. Ovo su i važni faktori koji mogu pokrenuti i reindustrijalizaciju privrede RS.

Važna poruka rada, koja bi mogla biti od koristi za vladu, jeste važnost vođenja odgovarajuće ekonomske i industrijske politike kojima se podstiču strukturne promene. Takođe, bitno je da se ne sme zanemariti koncept usaglašenog i balansiranog razvoja između sektora.

\section{ENDNOTA}

1 Statistička klasifikacija ekonomskih aktivnosti u EU, skraćeno NACE, je klasifikacija ekonomskih aktivnosti Evropske unije; akronim NACE je izveden iz francuskog Nomenclature statistique des activités économiques dans la Communauté européenne. 


\section{REFERENCE}

Baldwin, R., Braconier, H., \& Forslid, R. (2005). Multinationals, endogenous growth and technological spillovers: Theory and evidence. Review of International Economics, 13(5), 945963. doi: 10.1111/j.1467-9396.2005.00546.x

Bortis, H. (2000). Some considerations on structure and change. Structural change and economic dynamics, 11(1-2), 185195. doi.org/10.1016/S0954-349X(99)00028-4

Chenery, H. B. (1975). The structuralist approach to development policy. The American Economic Review, 65(2), 310-316.

Cimoli, M., \& Katz, J. (2003). Structural reforms, technological gaps and economic development: A Latin American perspective. Industrial and corporate change, 12(2), 387-411. doi.org/10.1093/icc/12.2.387

Croitoru, A. (2012). Book review Schumpeter, J. A. 1934 (2008). The Theory of Economic Development: An Inquiry into Profits, Capital, Credit, Interest and the Business Cycle. Journal of Comparative Research in Anthropology and Sociology, 3(2), $137-148$.

Jakopin, E. (2012). Post-crisis reallocation of growth factors. Economic Horizons, 14(2), 79-90. doi: 10.5937/ekonhor1202077J

European Commission (EC). (2008). NACE Rev. 2 - Statistical classification of economic activities in the European Community. European Commission, Eurostat, Brussels.

European Commission (EC). (2012). A Stronger European Industry for Growth and Economic Recovery. European Commission, Eurostat, Brussels.

Fagerberg, J. (2000). Technological progress, structural change and productivity growth: A comparative study. Structural change and economic dynamics, 11(4), 393-411. doi.org/10.1016/ S0954-349X(00)00025-4

Lewis, W. A. (1954). Economic development with unlimited supplies of labour. The Manchester school, 22(2), 139-191. doi: 10.1111/j.1467-9957.1954.tb00021.x

Lin, Y. J. (2012). New Structural Economics: A Framework for Rethinking Development and Policy. Washington, USA: World Bank, 5.

Machlup, F. (1991). Economic semantics. New Jersey, USA: Transaction publishers.
Marjanović, V. (2010). Značaj i uticaj privredne strukture na privredni razvoj. Ekonomske teme, 48(3), 369-382.

Marjanović, V. (2015). Strukturne promene i strukturna transformacija u savremenoj razvojnoj ekonomiji. Ekonomske teme, 53(1), 65-84.

Mićić, V. (2016). Strukturne promene i konkurentnost prerađivačke industrije Republike Srbije, U: V. Marinković, V. Janjić, i V. Mićić, (Red.). Unapređenje konkurentnosti privrede Republike Srbije (str. 153-161). Kragujevac, Republika Srbija: Ekonomski fakultet Univerziteta u Kragujevcu.

Moore, J. H. (1978). A measure of structural change in output. Review of Income and Wealth, 24(1), 105-118. doi: 10.1111/j.14754991.1978.tb00034.x

Republički zavod za Statistiku (RZS). (2010). Klasifikacija delatnosti. Beograd, Republika Srbija: Republički zavod za Statistiku.

Republički zavod za statistiku (RZS). (2017). Statistička baza podataka. Beograd, Republika Srbija: Republički zavod za Statistiku.

Roman, Z. (1969). A note on measuring structural changes. Review of Income and Wealth, 15(3), 265-268. doi: 10.1111/ j.1475-4991.1969.tb00809.x

Rowthorn, R. E., \& Ramaswamy, R. (1997). Deindustrialization: Causes and implications. IMF Working Paper 97/42.

Savić, Lj., Bošković, G., \& Mićić, V. (2015). Structural changes in manufacturing industry at division level - Serbia and new EU member states. Industrija, 43(4), 25-45. doi: 10.5937/ industrija43-8484

Syrquin, M. (2008). 4 Structural change and development. International Handbook of Development Economics, 1, 48.

Timmer, C. P., \& Akkus, S. (2008). The structural transformation as a pathway out of poverty: Analytics, empirics and politics. Working Paper, No. 150.

United Nations (UN). (2008). International Standard Industrial Classification of All Economic Activities. Revision 4, Statistical papers Series M, No. 4/Rev.4, United Nations Industrial Development Organization. 
UNIDO. (2013). Industrial Development Report 2013, Sustaining Employment Growth: The Role of Manufacturing and Structural Change. United Nations Industrial Development Organization.
Upadhyaya, S., \& Yeganeh, S. M. (2015). Competitive Industrial Performance Report 2014. Working paper series, 12/2014, 1011, United Nations Industrial Development Organization.

Primljeno 8. aprila 2017, nakon dve revizije, prihvaćeno za publikovanje 24. aprila 2017. Elektronska verzija objavljena 28. aprila 2017.

Vladimir Mićić je vanredni profesor na Ekonomskom fakultetu Univerziteta u Kragujevcu, gde je i doktorirao. Izvodi nastavu na nastavnim predmetima Ekonomika industrije, Privredni razvoj i Ekonomika rasta i razvoja. Oblast njegovog istraživačkog interesovanja su relevantna pitanja razvoja industrije, industrijske politike, strukturnih promena i privrednog razvoja. 


\title{
ECONOMIC DEVELOPMENT OF THE REPUBLIC OF SERBIA DETERMINED BY THE SECTORAL STRUCTURE OF THE ECONOMY
}

\author{
Vladimir Micic \\ Faculty of Economics, University of Kragujevac, Kragujevac, The Republic of Serbia
}

Experience and good practice show that, in order to achieve economic growth and development, changes in the economic structure need to be made. They have an influence on the relative share, place and role of certain activities in the economy and they are the driver of sustainable economic development. Efficient structural changes are related to the capability of an economy to create more propulsive economic activities. The subject matter of the research in this paper is the determination of the degree of the determination of the economic development of the Republic of Serbia by the sectoral structure of the economy. The research goal is to indicate the adequacy of the size of and contribution of the sectors to the creation of gross value added and the total employment, i.e. the influence of the size, intensity and directions of changes between the sectors on the economic development. The research results are indicative of the fact that the achieved level of the development and low growth rate of the economy of the Republic of Serbia are the consequence of insufficiently comprehensive and intensive changes, changes that are late and are not stable. The future development of the economy will directly depend on the speed of changes and the creation of a modern sectional economic structure, especially the development of a propulsive manufacturing structure or " 4.0 industries".

Keywords: economic development, structural changes, economic growth rate, employment, value added

JEL Classification: L16, O11,O47, E24, H24 